\title{
Revisioning progress
}

\author{
Auch am Anbruch des driften Jahrtausends brauchen wir dringend Visionen. \\ Diese können sich jedoch nicht mehr an der alten linearen Fortschrittsidee des \\ Westens orientieren, die bisher Ökonomie und Gesellschaft prägte. Angesichts \\ der bestehenden kulfurellen Vielfalt ist ein "koevolutionärer Flickenteppich" \\ als Ergebnis der dynamischen Interaktion von Kulturen und Ökosystemen das \\ passende Leirbild der anbrechenden neven Ära. Die ökologischen und sozialen \\ Risiken des Übergangs sind jedoch erheblich. Daher gilt es, sich neu öffnende \\ Nischen für ein Vorantreiben der Veränderungen zu nutzen.
}

$\mathrm{T}$ Von Richard B. Norgaard he third millennium arrives with a fraction of the collective hope initiating the final century of the second. Individuals still have private hopes. There are proposals for economic incentives to harness private interest to specific collective goals. But to dream of a really different and better future for all, however, is to risk being labeled a relic of the past. Yet new collective dreams are desperately needed. Our old hopes for progress contradict how reality has unfolded and provide little basis for looking ahead and guiding us collectively. We embrace expanding material possibilities while struggling with the unexpected effects of past new technologies. We trumpet an information age and the spread of democracy while trapped in spot infomercials and corporate politics. We appeal to rationality amidst science wars. We laud the global village while rich and poor accelerate apart. We cling to peace through cultural convergence amidst on-going ethnic violence. Without a vision that has the possibility of moving humanity beyond the contradictions of old hopes and current realities, contemplating the future neither refreshes nor inspires. Without serviceable hopes, the future is old before it has arrived.

Thus I dream of a new dream. Compared to earlier utopian visions, mine is a meta-dream that allows others to fulfill different dreams. The trouble with utopian thinking was that it envisioned a single future best for all. Perfection does not take multiple forms. When we lived in separate cultures, our separate hopes of perfection were less prone to clash. During the 20th century the powerful declared a convergence toward one utopia as many adopted the western belief in progress. Now, in spite of economic globalization, it is clear that separate cultures persist and evolve with their own hopes for the future. And with a population of 6 billion, our cultures are crowded together and overlapping. So we need a meta-vision under which our multiple cultural hopes can prosper without threatening each other. Of course, we will need sufficient global community to avoid global catastrophes. Yet global catastrophe will be less likely when we are not all striving by the same technological means to achieve the same economic ends. Thus the meta-dream should both facilitate multiple cultures doing things differently as well as provide the grounds for sufficient cooperation so we can be different in peace.

\section{The Western idea of progress}

Every culture has a life story. Judeo-ChristianIslamic religions introduced a life story wherein the earth, plant and animal life, and people were created separately and sequentially following what came to be interpreted as a grand design. Western philosophers took this story several steps further by imagining people and how they perceived and thought as outside of the world over which they had dominion, much like God was imagined. In this next imaging, God's grand design awaited the advance of human knowledge. To facilitate human prediction and control, the sequential authors of the Western narrative assumed universal underlying mechanical relations between parts throughout nature. Even biology still advances largely by using the analogy of a machine of lifeless parts. And economics, whether neoclassical or Marxist, addresses the accumulation of material things rather than the interconnectedness of people in human communities and nature. Progress is made by knowing more, gaining control over nature, and thereby having more material things.
Western people's belief in progress and ability to infect others around the globe with the same belief has defined the last two centuries. Western science, technology, social organization, and even religion were expected to provide all with a future increasingly free of material want and to foster international harmony. The idea of progress is linear and unifying. It casts our future in a manner improbably different from our past. History, I argue, can best be described as a process of cultures coevolving within and between themselves. We may be at a loss for dreams now because the linear vision of progress proved inoperable in a coevolutionary world.

\section{Coevolutionary patchwork quilt}

Our understanding of development has drawn on diverse metaphors of change. Economies have been portrayed to develop like embryos grow, to go through stages of growth like the morphogenesis of caterpillars into butterflies, and to progressively improve through increases in the accumulation of physical capital and human knowledge. These metaphors have everything developing in a known direction. In contrast to these, development can be portrayed as a process of coevolution between knowledge, values, organizational, technological, and environmental systems where the future is unknown (Figure 1). In the coevolutionary portrayal, each system is related to each of the others, yet each is also changing and affecting change in the others. Deliberate innovations, chance discoveries, random changes, and chance introductions occur in each system which affect the fitness and hence the distribution and qualities of components in each of the other systems. Whether new components prove fit depends on the characteristics of each of the systems at the time. With each system putting selective pressure on each of the others, they coevolve in a manner whereby each reflects the other. Coevolution explains how everything appears to be tightly locked together, yet everything also is changing.

Until merely a few centuries ago, the world could be thought of as a patchwork quilt of coevolving cultures and ecosystems. The dominant coevolutionary processes occurred within patches associated with specific human cultures. Boundaries, however, were neither distinct nor fixed within this coevolving mosaic. Knowledge, values, aspects of social organization, technologies, and species spilled from the patches within which they initially coevolved to become exotics 


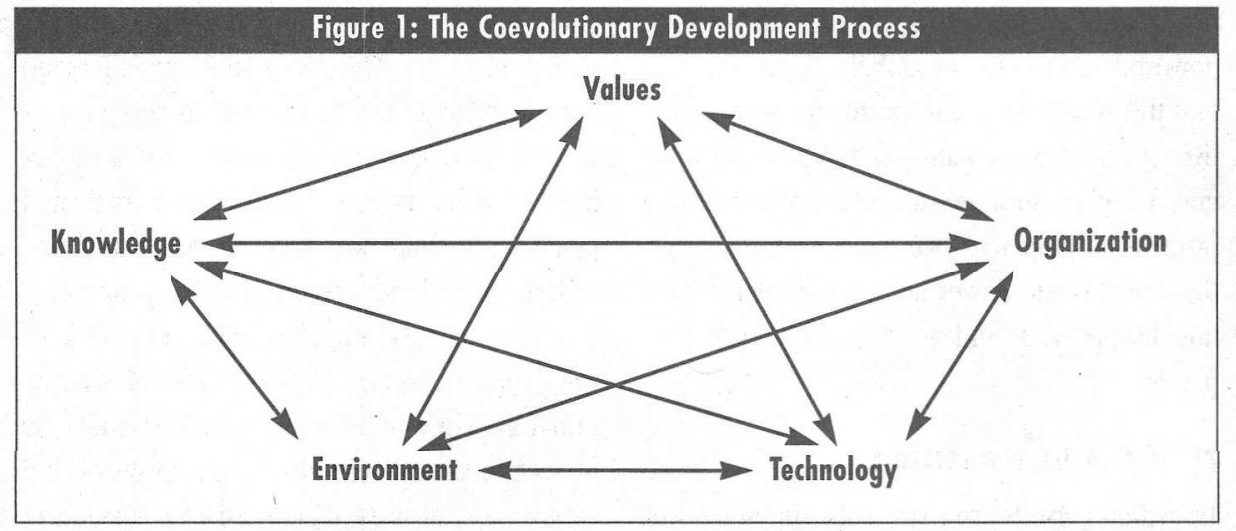

Source: Norgaard 1994 (see reference)

in other areas. Some of these exotics proved fit as they arrived and thrived in their new areas, some adapted, and some died out. But to some extent, they all influenced the subsequent coevolution of patch characteristics in their new areas, resetting the dynamics of the change in the composition of characteristics, their structural relations, and spatial area. The plethora of combinations within each patch kept the global pattern of coevolving species, myths, organization, and technology patchy, albeit a constantly changing, fuzzy, patchy.

The coevolutionary patchwork quilt was subsequently homogenized by the dominance of western science, technology, social organization, and beliefs. Fossil hydrocarbons provided a new energy source which - with the advent of steam technologies, chemical industries, and later the internal combustion engines - drove a "wedge“ in the coevolutionary process. This seemed to free people, at least in the short-run, from being interdependent with and coevolving with nature. Social organization coevolved with the new power, and with progress now self-evident, this material advantage was soon sought by all. And belief in progress softened the acceptance of the imperialism of Western science, technology, governance, economics, and religion.

\section{Towards a new era}

Now the simple gains of the short run are mixed with the complex consequences of the long run. Climate change and biodiversity loss make it clear that we are still coevolving with nature, just over longer time periods and now in unfavorable ways. The homogenization of cultures neither proved so easy nor so desirable as expected. Unceasing outbreaks of war around a multitude of differences make it clear that unity has not been won. Most people still seem to accept the final convulsions of modernity as the way life will is but one reality. That presumption justified disciplines and debates between scientists supported by different interests. Since the enlightenment there has been the presumption that our analyses of small parts of reality would dividing learning into the many little disciplines that now can't speak to each other, let alone help us put the great picture together. But now science has multiple voices for another reason as well. Individual scientists and whole research institutions have accepted the task, increasingly consciously, of learning and speaking for special interests. In a positive feedback loop, teaching and research institutions have been losing public stature and broad support, making them also ever more susceptible to and dependent on special interests.

The combination of sciencratic paralysis and special interest science has created a void, an opportunity for new things to coevolve. Filling this niche, we are beginning to see a new understanding of how science could work. The best example is the Intergovernmental Panel on Climate Change. Astrophysicists, ecologists, oceanographers, economists, and other specialists not merely add together their findings but rather are learning interactively and making judgments collectively.

\section{Changing governance}

As progressive governance has declined over the past two decades, we have also seen thousands of biologists switch from "being objective" and letting change fall where it may to ,having an objective," the conservation of biological diversity. Economists have joined with ecologists to develop an ecological economics. New participatory research techniques entail learning with local peoples, sharing in mutually designed and implemented research and demonstration projects. Diverse groups are also uniting to share values and understandings. Conflicts are being resolved through new mediation techniques and through the use of science juries as well as value juries. There is a lot of change going on that is moving in an interesting direction.

The niche progressive governance once filled is also being encroached upon by an explosion of non-governmental organizations (NGOS). This new form of social organization is substituting for loss of community, as well, and also evolving to fit entirely new niches in response to the problems modern forms of organization have created. We see a global ,NGOization" with networks being formed between environmentalists, laborers, and indigenous peoples. New forms of civil society are coevolving to fit new spaces. No one foresaw the success of this general form or all of its emerging particulars. This new family of 


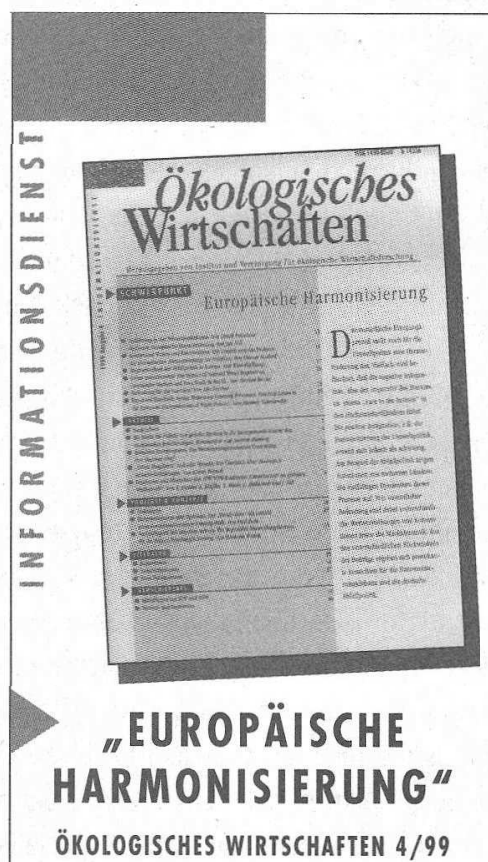

Der europäische Einigungsprozess stellt insbesondere für die Umweltpolitik eine Herausforderung dar. Die unterschiedlichen Wertvorstellungen, Konventionen und Umweltgesetze müssen in Einklang gebracht werden. Kommt es dabei in den Hochstandardländern zu einem "race to the bottom" wie vielfach befïrchtet oder gelingt eine Harmonisierung, die den Umweltschutz vorantreibt? Dieser Frage geht Ökologisches Wirtschaften am Beispiel der Abfallpolitik nach. AutorInnen aus mehreren Ländern beleuchten aus unterschiedlichen Blickwinkeln die vielfältige Dynamik dieses schwierigen Harmonisierungsprozesses.

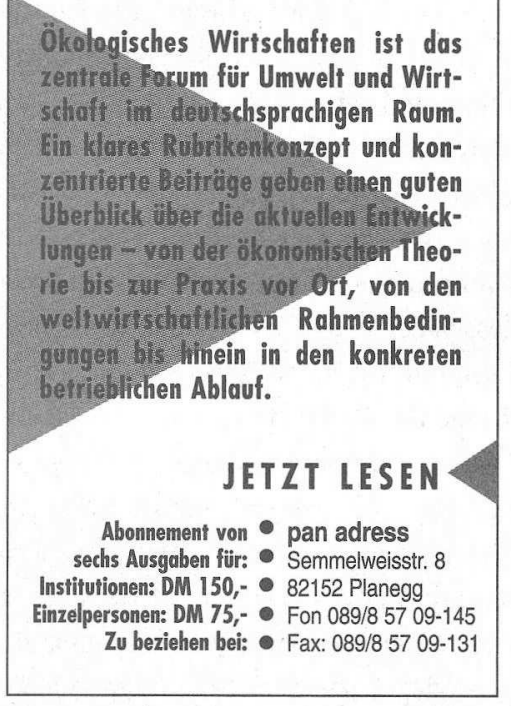

organizational species is proving surprisingly powerful in the face of global capital. The fact that the World Bank can no longer work effectivcly without participating with NGOs and bringing in other speakers to their gatherings is a positive development. We still, of course, have the World Bank. Power and central places have not disappeared. And yet new things are happening.

\section{Risks of transition ...}

Transition periods are risky. This cannot be over stressed. National breakups have resulted in the re-emergence of cultural warfare with disastrous consequences for many. After centuries of fighting over which economic banner to unify under, we are ill-equipped to handle diversity as a state of being and goal for the future. There are other risks as well. Both World Bank leaders and environmentalists talk about sustainable development as if all countries were as socially and politically stable as Costa Rica, which is the "Switzerland" of the Americas. Few modernists see the significant cultural, economic, and environmental consequences of social conflict within and between nations. We have many nations breaking apart and more that are likely going to dissolve. We're going to experience more war. These disruptions will have tremendous biological, cultural, and organizational consequences. It's especially risky because we can no longer pretend to share a common language of modern rationality, or common hopes to bring us together.

There is some chance, unfortunately, that our impoverished economic ideology of all social organization being about voluntary exchange will succeed long enough to have serious impacts. I don't think it will succeed over a very long period, but nomadic capital comes with tremendous risks in our overcrowded, environmentallystressed world. The development of the Asian financial crisis documents that we still think we are in the world we tried to establish after World War II. Old responses to current social and environmental problems will only exasperate our situation. The lag in our interpretations of where we are may be the greatest risk to coevolutionary potential at this time.

\section{$\checkmark$... and new opporfunities}

Drastic change has its risks, but there are also new opportunities. We need to start thinking about new, multi coevolutionary possibilities after some five centuries of dominance by the idea of progress. The coevolutionary understanding of process can contribute to this revisioning. It once again places us and how we think inside a great life story among the animals and plants with whom we share the mountains and valleys, rivers and oceans. The coevolutionary cosmology stresses the communal nature of knowing, making social life a process of sharing rather than of vote counting and enforcement, or of technocrats determining right answers and controlling our lives. It emphasizes the beauty of participating in and sustaining a coevolutionary unfolding rather than the individual glory of power and material accumulation. It values both nature and people. It draws upon recent advances in Western science as well as upon Western values which have withstood the test of time. And most importantly, it gives legitimacy to and a philosophy for interacting with the plurality of evolving human cultures and their distinct yet changing life stories. This framing can contribute to the process of revisioning progress.

In this time of change, we need to identify where positive changes are occurring as well as negative developments so that we can participate somewhat deliberately in history's unfolding. We must find spaces where we can work effectively, sometimes simply to hide from destructive change, but eventually to show a new direction, a new vision. As the collapse of progress occurs, we need an alternative to total disaster. We can help construct interesting spaces in the transition to a new world. It is unclear what this will be like, but I will be dreaming of and acting on a coevolutionary patchwork quilt of cultures.

\section{Reference}

Norgaard, Richard B.: Development Betrayed: The End of Progress and a Coevolutionary Revisioning of the Future. Routledge, London and New York, 1994.

\section{Der Autor}

Richard B. Norgaard ist Professor für Energie sowie Agrar- und Ressourcenökonomie an der University of California und Präsident der International Society for Ecological Economics (ISEE). Kontakt: Energy and Resources Program, 310 Barrows Hall, University of California ot Berkeley, Berkeley, California 94720-3050, USA. Tel. 001-510642-3465, Fax -1085, E-mail: norgaard@igc.org 
(c) 20I0 Authors; licensee IÖW and oekom verlag. This is an article distributed under the terms of the Creative Commons Attribution Non-Commercial No Derivates License (http://creativecommons.org/licenses/by-nc-nd/3.o/), which permits unrestricted use, distribution, and reproduction in any medium, provided the original work is properly cited. 